\title{
The Effectiveness of Audio Visual Media on the Learners' Skill in Writing Fable Text 1
}

\author{
Elpi Zulita \\ IAIN Bengkulu \\ Elvizulita22@gmail.com \\ Sukarno \\ IAIN Bengkulu \\ Upma.sukarno@gmail.com \\ Bustomi \\ IAIN Bengkulu \\ Bustomi.hasan@iainbengkulu.ac.id
}

\begin{abstract}
This research was intended to determine the frequency of the effectiveness of audiovisual media towards the first grade students of SMP Negeri 1 Kaur in learning fable texts. To reveal these problems in depth and thoroughly, this research was designed by using the true experimental method using Post Test Only Control Design. The results of the study showed that the implementation of using audio-visual media in writing fable texts by class VII A obtained an average score of 75.38 while writing fable texts without using audio-visual media by class VII B SMP Negeri 1 Kaur obtained an average score of 65.96. The result showed that the implementation of Audio visual media in writing fable text was effective. It could be proven through the calculation of t-test which obtained $t_{\text {hitung }}>t_{\text {tabel }}=2,738>2,056$. In this case, there was a significant difference in using audio-visual media without using audio-visual media on the students' skill in writing fable text by class VII A and VII B SMP Negeri 1 Kaur. Audio-visual media could be deemed effective for the students in learning fable texts better.
\end{abstract}

Keywords: Effectiveness, Audio visual media, writing skills, fable text.

\section{A. Introduction}

Education can be deemed as one of the most crucial aspects in human life since it has become the basis of great civilization in the modern era. Moreover, it can refer to the process of personality development and skill enhancement. Sadirman states that if ones have changed their old behaviour to the new one, it can be recognized that they have learned or have been through a learning process. It happens as there is an interaction and a communication in the process. Thus, students will adapt to this era, and they will be able to be competitive individuals for the better life (2019).

In the Indonesian learning process, there are four skills that should be mastered by the learners i.e listening, speaking, reading, and writing. One of the 
most difficult skills can refer to the writing skill as this skill also relates to comprehension, imagination, and creativity. This skill enables students to promote and express their creativity. Thus, it also has a good impact on the learners' mental, intelligence, and social skills. Tarigan argues that writing activity is intended to declare and express facts, ideas, or points of views clearly and effectively to others (readers). As one of language skills, it can be seen as a complex skill as it needs the ability to compile their ideas in the form of written language varieties. Therefore, the process of writing has an effective impact in developing students' intelligence and social skills (2020).

Effectiveness can relate to the success achieved by someone to show the ability in achieving certain objectives that can be measured through the quality, quantity, and time in accordance with the stated objectives. Related to this case, it can be seen clearly that there are two different terms. They are effective and learning. Thus, it can be stated that effectiveness refers to efficiency and accuracy. According to Kamus Besar Bahasa Indonesia (KBBI), effectiveness is driven from the word "effective" which has effect, impact, and influence. In other words, it can refer to a satisfied outcome (Depdiknas, 2000).

The implementation of audio visual as the learning media can be one of the alternatives in avoiding the students' learning difficulties. Audio visual is something important for teachers as it can help the teachers in delivering learning materials effectively. This learning media is deemed more real to be implemented than the lecture method.

Learning media is very crucial for teachers and students in the learning process. By using an appropriate learning medium, it can be easier for the students to comprehend the learning material, and it can enhance the students' learning motivation. It can be textbooks, video, audio, and so forth. Thus, it can be claimed that learning media have a crucial role in teaching and learning process.

Furthermore, the researchers implemented animation video as the learning medium in this research. This learning medium has some advantages. It can promote the students' learning motivation, and it can make a pleasant learning 
process. Moreover, it can enhance the students' comprehension towards learning material being discussed.

Danandjaya points out that fable is a fantasy story whose characters can be pets, wild animals, mammals, birds, reptiles, fish, and insects (2020). Fabel text also refers to a story in which the characters are ruled by animals. This text has moral values for the readers.

The implementation of the audiovisual can promote the students' creativity and interest in learning material. In this case, teachers should be able to choose and implement the appropriate learning media in their class since the implementation of similar learning media repeatedly will have a negative impact on the learners' learning motivation.

Based on the preliminary observation conducted by the researchers at the SMP Negeri 1 Kaur, the students still had poor ability in writing fable text. It could be seen from the lack of ability in choosing words (diction), spelling, and implementing the right structures of the text. In this case, the students were still not able to develop their imagination and creativity in writing the text. It was caused by the lack of learning innovation and variation in the learning process. Therefore, the learning process using audio visual as the learning medium should be implemented to enhance the students' learning enthusiasm and interest.

In the context of the aforementioned cases, the researchers were interested in conducting the research entitled "The Effectiveness of Audio Visual Media on the Learners' Skill in Writing Fable Text at the First Grade Students of SMP Negeri 1 Kaur" because the students still had poor ability in writing fable text.

\section{B. Research Method}

This research was designed by using a quantitative approach and quasiexperimental design method. The research is intended to provide the truth of the facts related to the research issue through numeration and computation

Moreover, Robert Donmoyer states that a quantitative approach is used to collect, analyze, and display empirical studies in the form of numerals instead of narration (2013). The research data by using this approach can be numbers 
analyzed by using statistics techniques. This research is aimed to verify the relationship between variables, to determine the quality of variables, to test theories, and to reveal predictive generalization. This approach can also be used to canvass a certain population or sample randomly. The research collection technique implemented instruments using statistics.

This research was conducted in SMP Negeri 1 Kaur for one month started from March to April. In this case, the research data were collected from the students' learning results in writing fable text through essay writing tests.

\section{Result and Discussion}

\section{Result}

Data in this research were the students' skill in writing fable text at the first grade students of .SMP Negeri 1 Kaur collected using two different treatments to each group. The first group were given treatment (experiment), while the second group were not given such treatment (experiment).

\section{a. Test of Normality}

Table 4.12

Test of Normality

\begin{tabular}{|c|c|c|c|c|c|c|c|}
\hline \multirow[b]{2}{*}{ Kelas } & & \multicolumn{3}{|c|}{ Kolmogorov-Smirnov $^{a}$} & \multicolumn{3}{|c|}{ Shapiro-Wilk } \\
\hline & & Statistic & Df & Sig. & Statistic & $\mathrm{df}$ & Sig. \\
\hline \multirow{10}{*}{$\begin{array}{l}\text { Hasil } \\
\text { Belajar } \\
\text { Siswa }\end{array}$} & PreTest & , 109 & 26 & $.200^{*}$ & ,941 & 26 & , 141 \\
\hline & Eksperime & & & & & & \\
\hline & $\mathrm{n}$ & & & & & & \\
\hline & PostTest & , 178 & 26 & 033 & ,960 & 26 & ,393 \\
\hline & Eksperime & & & & & & \\
\hline & $\mathrm{n}$ & & & & & & \\
\hline & PreTest & , 137 & 26 & $.200^{*}$ & ,897 & 26 &, 014 \\
\hline & Kontrol & & & & & & \\
\hline & PostTest & , 126 & 26 & $.200^{*}$ & ,954 & 26 & ,293 \\
\hline & Kontrol & & & & & & \\
\hline
\end{tabular}

Sumber: SPSS 2000 
Seen from the table 4.12 above, it could be seen that the value of significance of each variable was more than 0,05 . Thus, the data were normally distributed.

\section{b. Test of Homogeneity of Variance}

Table 4.13

Test of Homogeneity of Variance

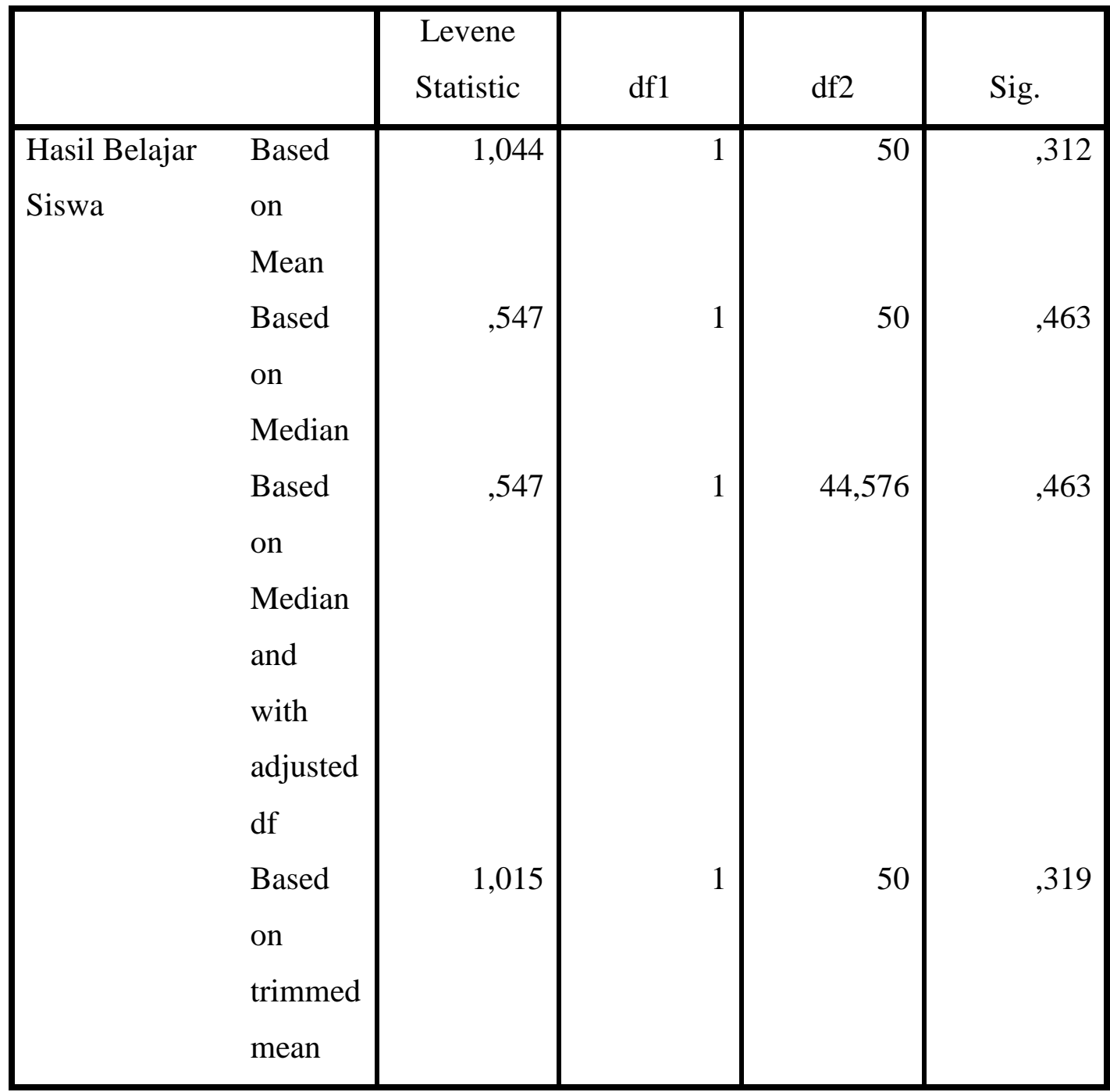

Sumber: SPSS 2000

Seen from the table 4.13 above, it could be revealed that the value of significance of each variable was more than 0,05 . Thus, it could be deemed that the data which had variation on each sample were homogenous. 
Table 4.14

Independent Samples Test

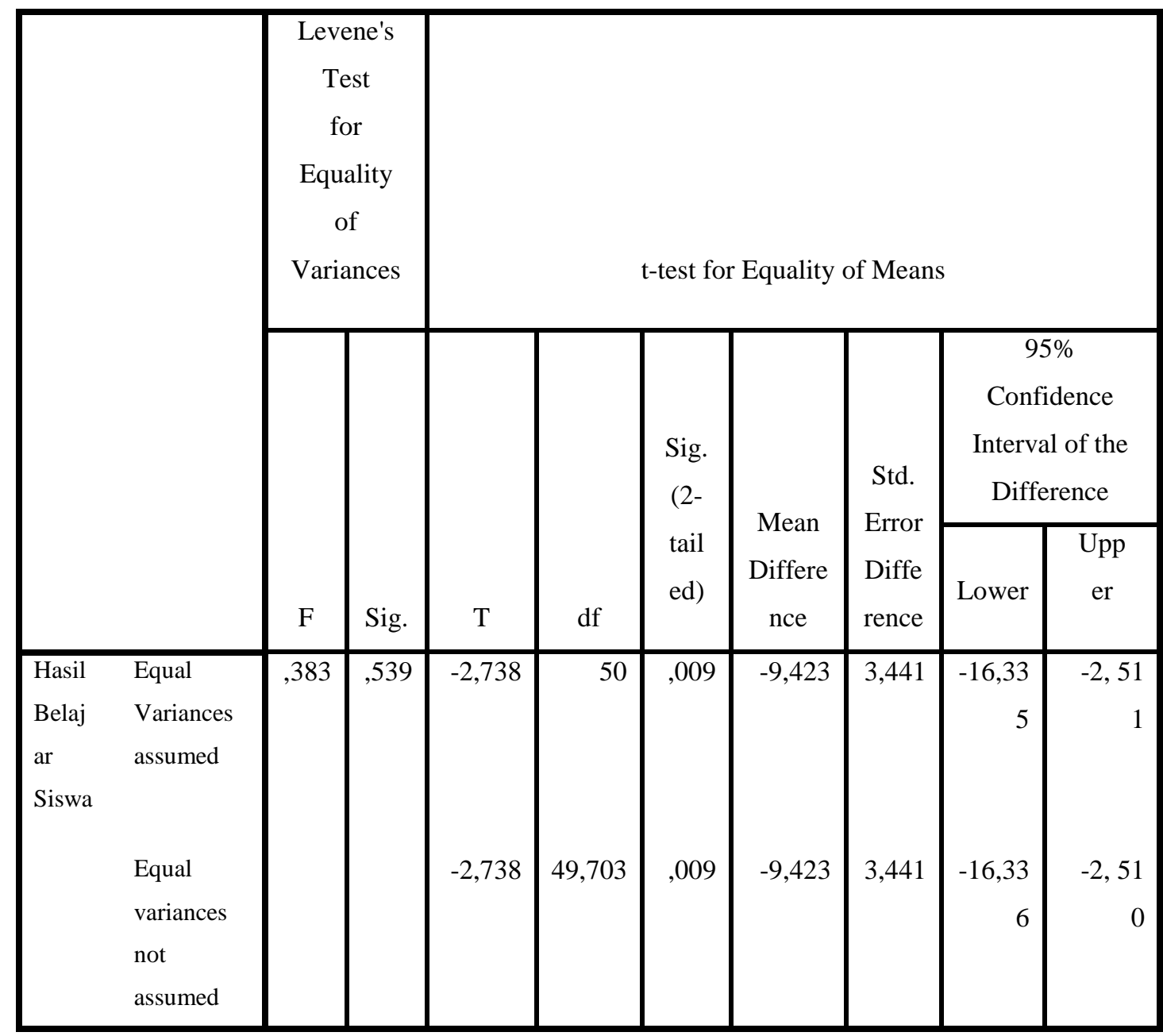

Sumber: SPSS 2000

Seen from table 4.14 above, the result of an independent sample t-test revealed that the test value $t_{\text {hitung }}=2,738>t_{\text {tabel }}=2,056$ and the significance was $95 \%$ with $\alpha=0,05$. Thus, it could be seen that there was a different average between the students' skill in writing fables in the experiment class and control class. It revealed that the implementation of audio visual was effective on the students' skill in writing fables among the first grade students of SMP Negeri 1 Kaur. 


\section{Discussion}

Writing skill could be one of the students' weaknesses as it was caused by the lack of the students' learning interest, creativity, and imagination development. Moreover, the implementation of learning media by the teachers still has a lack of variation. One of the ways to overcome the case is by implementing audio visual as the learning medium. In this case, Azhar Arsyad (2014: 19) argues that the use of learning media in the process of teaching and learning can enhance students' new interest, motivation, and stimulation of learning activity. It also have influences on the students' psychology. Zhamarah dan Zain (2006: 120) explains that learning media can relate to anything that can be used as the learning medium to deliver the information and message to the students in achieving the learning goal. Thus, learning media can represent teachers' limitations in delivering certain material through their words.

Dunne (1996: 26) states that the effectiveness of learning has two characteristics. The first characteristic is that it should be able to facilitate students in learning something useful, such as facts, skills, values, concepts, or intended learning achievements. The second characteristic is that competency should be admitted by those who have competence in evaluating, such as teachers, tutors, supervisors, or students themselves.

Based on the research result, it revealed that the implementation of audio visual as the learning media in the Indonesian learning process was effective in enhancing the students' skill in writing fable text. It was intended to promote the students' learning interest. Moreover, the monotone material presentation had a negative impact on the learners' learning motivation. Meanwhile, the implementation of audio visual had a positive impact on the students' imagination and creativity development in writing fable text. It could be gained by the students' deep comprehension towards the learning materials and animation on the learning media being used.

In this research, the researchers implemented a learning medium on the basis of animation video. This learning medium had some advantages, such as it could promote the students' learning interest, comprehension, and enjoyment. 
Furthermore, based on the result of hypothesis test using t-test towards both groups. It was found that the results showed $t_{\text {hitung }}=2,738>t_{\text {tabel }}=2,056$. Thus, it could be concluded that t-test significance $\left(\mathrm{H}_{\mathrm{a}}\right)$ in this research was accepted and recognized as there was the difference between the students' skill in both experiment class and control class. Thus, it could be concluded that the implementation of audio visual was effective on the learners' skill in writing fable text at the first grade students of SMP Negeri I Kaur.

\section{Conclusion and Suggestion}

\section{Conclusion}

Based on the research result, the researchers conclude that the implementation of audio visual on the learners' skill in writing fable text is effective. It can be proven by the result of t-test gained through SPSS which shows that $\mathrm{t}_{\text {hitung }}=2,738>\mathrm{t}_{\text {tabel }}=2,056$. It is proven clearly that there is a significant difference in using audio-visual media without using audio-visual media on the students' skill in writing fable text by class VII A and VII B SMP Negeri 1 Kaur. Audio-visual media can be deemed effective for the students in learning fable texts better.

\section{Suggestion}

Based on the results of the research, the researchers conveys several suggestions for the teachers, the students, the principal, and the researchers, as follows:

a. The teachers should often innovate the learning media so that students have high learning enthusiasm, motivation, and interest. It can be conducted by using props or media that can support the learning process. In addition, if the teachers want to use audio-visual as the learning media, they do not only need to prepare the necessary supporting tools, but also they need to adjust the lighting of the classroom so that the projected media is clearly visible to students so that students can feel comfortable in using the media.

b. The students should be more diligent and active in learning, especially in enhancing their skill in writing fable text so that they can enhance the learning outcome. In this case, the students have to be able to develop their 
imagination and creativity. Moreover, they should apply the moral values found in the fable text in their daily life.

c. The principal should be able to provide appropriate learning facilities to support the learning process.

d. For researchers, this research is expected to get new knowledge, and to increase their creativity and experience in making scientific works.

\section{References}

Aprima, R. (2018). Pengaruh Model Discovery Learning Terhadap Keterampilan Menulis Teks Fabel Siswa Kelas VII SMP Negeri 16 Padang," Pendidikan Bahasa Indonesia, (Online), 1(7),

Arief, S. (2010). Media Pendidikan: Pengertian, Pengembangan, dan Pemanfaatannya. Jakarta: PT Rajagrafindo Persada.

Asma, F. (2019). Media Audiovisual dalam Menulis Kembali Teks Cerita Fabel oleh Siswa Kelas VIII SMP Swasta Bandung. Asas: Jurnal Sastra, (Online), 9(1), 24.

Budi, P.S. (2013). Metodologi penelitian kuantitatif. Jurnal Bandung: UIN Sunan Gunung Djati, (http://komunikasi. uinsgd. ac.id, retrieved on 02 December 2020).

Depdiknas. (2008). Kamus Besar Bahasa Indonesia Edisi Keempat. Jakarta: Balai Pustaka.

Fransiska, S, (2013). Peningkatan Efektivitas Belajar Peserta Didik dalam Pembelajaran Ilmu Pengetahuan Sosial Menggunakan Media Tepat Guna di Kelas IV Sekolah Dasar Negeri 02 Toho. Jurnal Pendidikan dan Pembelajaran khatulistiwa, (Online). 2(7), 31.

Gustiana, D.H. (2018). Bahan Ajar Menulis Teks Fabel Bermuatan Nilai Kehidupan. Jurnal Pendidikan: Teori, Penelitian, dan Pengembangan, (Online), 3(8), 1.

Hidayah, N. (2018). Efektivitas Penggunaan Media Audio Visual dan Metode Eksperimen pada Materi Transpor pada Membran Sel Kelas Xi IPA di SMAN 1 Kluet Tengah Kabupaten Aceh Selatan. Online Thesis (https://bit.ly/2Zuczsz, retrieved on 22 November 2020).

Juliyanti, P. (2019). Efektifitas Penggunaan Media Audio Visual Melatih Pendengaran dan Daya Ingat Anak Usia Dini di Paud Barunawati Kota Bengkulu. Skripsi S-1 Fakultas Tarbiyah dan Tadris, Institut Agama Islam Negeri Bengkulu, (https://bit.ly/3pwO0G8, retrieved on 17 February 2020). 
Khulbania, M. (2019). Pengaruh Model Pembelajaran Make a Match Terhadap Hasil Belajar Mata Pelajaran Matematika Materi Kelipatan dan Faktor Bilangan Siswa SDN 06 Kaur. Skripsi S-1 Fakultas Tarbiyah dan Tadris, Institut Agama Islam Negeri Bengkulu,(https://bit.ly/3dqOw61, retrieved on 12 November 2020).

Sari R, I. (2016). Pengembangan Media Pembelajaran Menulis Teks Fabel dengan Macromedia Flash bagi Siswa SMP," Jurnal Pendidikan: Teori, Penelitian, dan Pengembangan. 1(7),2.

Santoso S. (2000). Statistik Parametrik. PT Elexmedia Kompitindo. (https://bit.ly/3gIpHm7, retrieved on 18 June 2021).

Sugiyono. (2015). Metode Penelitian Kuantitatif, Kualitatif, dan R\&D. Bandung: Alfabeta .

Suwandi, T. (2019). Pengembangan Media Pembelajaran Teks Fabel Kelas VII Smp Bayt Al-Hikmah Kota Pasuruan Berbasis Ispring. Jurnal 1(1), 21.

Widi, A.Y. (2014). Pengaruh Penggunaan Media Film Animasi Terhadap Keterampilan Menulis Karangan Narasi Siswa Kelas V SD. Jurnal Prima Edukasia, 2(2),31. 